UDC 577.352.4

\title{
Identification of nitric oxide in mitochondria of myometrium cell
}

\author{
Yu. V. Danylovych, S. A. Karakhim, O. V. Kolomiets, G. V. Danylovych, S. O. Kosterin \\ Palladin Institute of Biochemistry, NAS of Ukraine, \\ 9, Leontovycha Str., Kyiv, Ukraine, 01601 \\ danylovych@biochem.kiev.ua
}

\begin{abstract}
Aim. To demonstrate the possibility of NO synthesis in intact myocytes of uterus. Methods. Confocal scanning microscopy method, NO-sensitive fluorescent probe DAF-FM, MitoTracker Orange CM- $\mathrm{H}_{2} \mathrm{~T}$ MRos. Results. The basal production of NO in intact myocytes was shown using DAF-FM. Incubation of myocytes with NO donor - sodium nitroprusside (SNP) - led to an increase of the DAF-FM-T fluorescent signal. On the contrary, the addition of NO-synthase inhibitor - N-nitro-L-arginine (NA) - results in the reduction of fluorescent intensity. It was demonstrated colocalizition of specific probe for mitochondria MitoTracker Orange CM- $\mathrm{H}_{2}$ TMRos and NO-sensitive dye DAF-FM. Conclusions. For the first time it has been demonstrated the presence of $\mathrm{NO}$ in smooth muscle cell mitochondria using laser confocal microscopy, NO-sensitive probe DAF-FM and specific marker of the functionally active mitochondria MitoTracker Orange CM- $\mathrm{H}_{2}$ TMRos.
\end{abstract}

Keyw or d s: nitric oxide, myometrium, DAF-FM, confocal microscopy.

\section{Introduction}

Nitric oxide (NO) plays an essential role in many physiological processes, particulary in vasodilation, neurotransmission, immune responses, etc. $[1,2]$. There are convincing proofs of the functional role of $\mathrm{NO}$ as a tocolytic agent. The ability of nitrocompounds to modulate activity of the $\mathrm{Ca}^{2+}$-transport system in myometrium cells was established [3]. At the same time, the identification of sources of its biosynthesis in the uterus myocytes is still a problem, because of a short time of existence and a high reactivity of nitric oxide.

The presence of the $\mathrm{Ca}^{2+}$-dependent isoforms of NO-synthase in mitochondria (mtNOS) was proved by immunohistochemical methods for single tissues [4-6]. On the one hand, nitric oxide can regulate the activity of electron transport chain in mitochondria through a reverse decrease in the cytochrome c-oxidase activity, and control of mitochondria $\mathrm{pH}$. On the other hand, an excess production of NO together with intensification of the superoxide anion formation in mitochondria is accompanied by the peroxynitrite generation, damage of the respiratory chain components, mitochondria depolarization and the apoptosis development [4-6]. So in general, the mitochondria and cells life and destruction depend on the level of NO production. This indicates the importance of identification of NO biosynthesis in the intact cells mitochondria.

Modern fluorescent probe DAF-FM allows the recording of NO production, even the registration of the low NO concentrations $(2-5 \mathrm{nM})$ in intact cells; the laser confocal microscopy method allows the visualization of the NO formation and the confirmation of the link of NO biosynthesis by these organelles using specific probe for mitochondria [4, 7].

So, the purpose of this work was to demonstrate the possibility of NO synthesis in the intact myocytes of uterus by energized mitochondria using the sensitive fluorescent dye DAF-FM, the selective

(C) 2015 Yu. V. Danylovych et al.; Published by the Institute of Molecular Biology and Genetics, NAS of Ukraine on behalf of Biopolymers and Cell. This is an Open Access article distributed under the terms of the Creative Commons Attribution License (http://creativecommons.org/licenses/by/4.0/), which permits unrestricted reuse, distribution, and reproduction in any medium, provided the original work is properly cited 
Identification of nitric oxide in mitochondria of myometrium cell

marker for mitochondria MitoTracker Orange CM$\mathrm{H}_{2}$ TMRos and confocal laser scanning microscopy.

\section{Materials and Methods}

Myocytes were isolated from the uteruses of white nonlinear nonpregnant rats, by the method of Mollard using collagenase and soybean trypsin inhibitor [8]. The animals were narcotized by inhalation of diethyl ether, after that they were decapitated. All regulations for the work with laboratory animals were maintained (International Convention, Strasbourg, 1986).

Spatial distribution of fluorescent dyes in cells was investigated by the confocal laser scanning microscope LSM 510 META («Carl Zeiss», Germany). Myocytes were immobilized on poly-L-lysine. The cell immobilization, removal of unattached myocytes and all experimental procedures were conducted in physiological Henks's solution (mM): $\mathrm{NaCl}-136,9$; $\mathrm{KCl}-5,36 ; \mathrm{KH}_{2} \mathrm{PO}_{4}-0,44 ; \mathrm{NaHCO}_{3}-0,26 ; \mathrm{Na}_{2} \mathrm{H}-$ $\mathrm{PO}_{4}-0,26 ; \mathrm{CaCl}_{2}-0,03 ; \mathrm{MgCl}_{2}-0,4 ; \mathrm{MgSO}_{4}-0,4$; glucose $-5,5$; Hepes $\left(\mathrm{pH}, 7,4,37^{\circ} \mathrm{C}\right)-10$ [9]. For myocytes permeabilization digitonin was added to the solution to a final concentration of $0.1 \%$.

For the visualization of mitochondria and cell nucleus the fluorescent dyes MitoTracker Orange CM$\mathrm{H}_{2}$ TMRos (200 nM) and Hoechst $33342(50 \mathrm{nM})$ were used respectively [10]. The loading of immobilized myocytes with NO-sensitive fluorescent probe DAFFM $\left(\mathrm{C}_{21} \mathrm{H}_{14} \mathrm{~F}_{2} \mathrm{~N}_{2} \mathrm{O}_{5}\right.$, 4-amino-5-methylamino-2',7'-difluorescein, diaminofluorescein-FM) in concentration $10 \mu \mathrm{M}$ was carried out for $15 \mathrm{~min}$ at $24^{\circ} \mathrm{C}$.

The experiments with confocal microscopy were performed in Multi Track mode. The Multi Track function permits several tracks to be defined as one configuration for the scan procedure. Each track is a separate unit and can be configurated independently of the other tracks with regard to channels. Fluorescence of Hoechst 33342 was excited using laser wavelength $405 \mathrm{~nm}$, and registered with the filter BP 420-480. For MitoTracker Orange CM-H TMRos, the fluorescence laser at the wavelength of $543 \mathrm{~nm}$ was used, and fluorescence was registered in the range of 560-615 nm (filter BP 560-615); DAF-FM fluorescence was excited at the wavelength $488 \mathrm{~nm}$, and the emission was collected in the $505-530 \mathrm{~nm}$ signal range (filter BP 505-530) [http://www.lifetechnologies.com/order/catalog/product/D23844, 9]. The study of fluorescent dye distribution in a cell was performed in Time Series mode. For the quantitative analysis of the time-dependent fluorescence intensity of the cell, the ROI (Region Of Interest) mode was used.

The data are presented as mean \pm SEM [10].

In the work the following reagents were used: Hepes, glucose, saccharose, digitonin, sodium succinate, bovine serum albumin, poly-L-lysine, collagenase type IA, ATP, Pluronic F-27, DAF-FM, EGTA, Ca$\mathrm{Cl}_{2}$ (Sigma, USA); $\mathrm{DiOC}_{6}(3)$, Hoechst 33342, soybean trypsin inhibitor (Fluka, Switzerland); MitoTracker Orange CM-H TMRos (Invitrogen, USA).

\section{Results and Discussion}

In the experiment an active acid form of DAF (DAFFM) was used. It interacts directly with $\mathrm{NO}$ in the presence of $\mathrm{O}_{2}$, forming triasole-fluorescein (DAFFM-T) derivative, that has high quantum yield of fluorescence $[7,11]$. The efficiency of DAF-FM entering into myoplasm was increased by permeabilization of the plasma membrane by $0.1 \%$ digitonin, although the dye can penetrate partially through the membrane into a cell by diffusion [12]. The treatment of cells by the detergent significantly reduces the contribution of NO-synthase associated with the plasma membrane in a fluorescent signal. On the other hand, the dye entering the mitochondria was increased. These studies revealed (Fig. 1), that there was green fluorescent signal after pre-incubation with DAF-FM. The result reflects a basal NO production [4]. The signal was not associated with the cells autofluorescence in this area. A high sensitivity of the used dye permits to register a basal level of $\mathrm{NO}$ in myocytes, that is formed as a result of the constitutive NO-synthase functioning.

The signal is detected in the cell myoplasm, mapping its contours and forming the heterogeneous dyed areas. There were the NO-positively dyed areas also in the nuclei, and sometimes outside the cells, as a result of the diffusion.

The incubation of myocytes with $0.1 \mathrm{mM}$ sodium nitroprusside (SNP) - NO donor - led to a substantial 


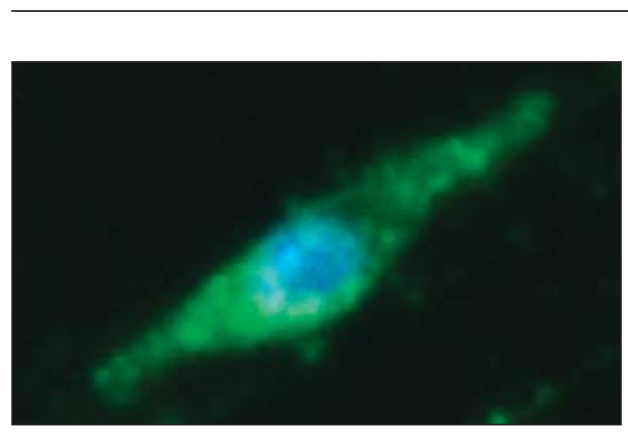

Fig. 1. Distribution of DAF-FM-T (green color) and Hoechst 33342 (blue color) fluorescent signals in myocyte
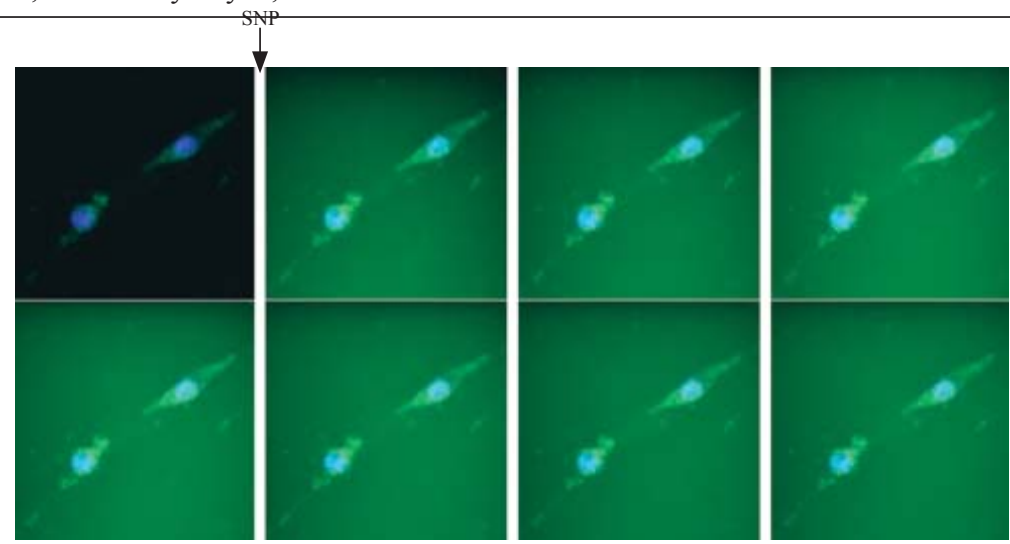

Fig. 2. Increase in the intensity of fluorescent DAF-FM-T signal in myocytes after SNP addition; DAF-FM-T - green color, nucleus probe Hoechst 33342 - blue color
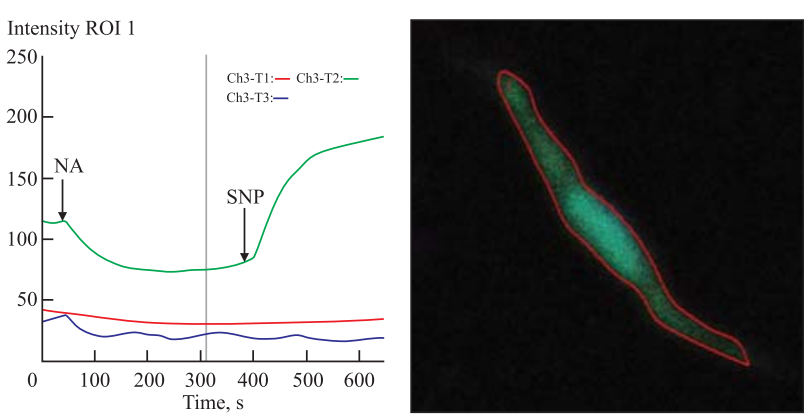

Fig. 3. Changes in fluorescent intensity of DAF-FM-T in myocytes with adding NA and SNP: MitoTracker Orange CM- $\mathrm{H}_{2} \mathrm{~T}$ MRos, red curve, channel 1; DAF-FM-T, green curve, channel 2; Hoechst 33342, blue curve, channel 3

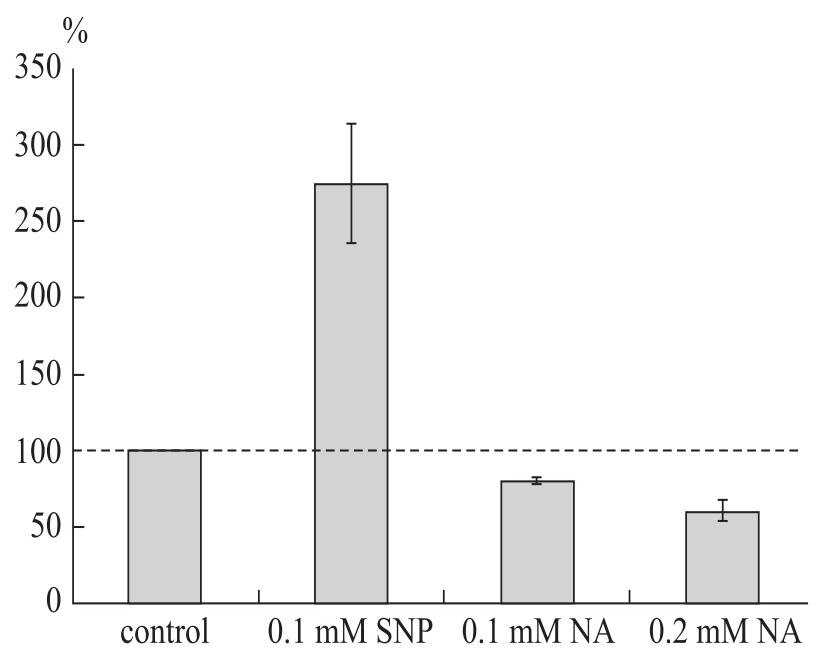

Fig. 4. Quantitative analysis of DAF-FM-T fluorescent intensity changes in myocytes after adding NA and SNP relative to controls without these substances $(100 \%) ; M \pm m, n=3-7$ increase of fluorescent signal (Fig. 2). The fluorescence increased in myocytes and outside the cells, because NO was generated by SNP outside the cells too.

The incubation of cells with increased concentration $(0.1$ and $0.2 \mathrm{mM})$ of N-nitro-L-arginine (NA) a nonselective inhibitor of the $\mathrm{Ca}^{2+}$-dependent isoforms of NO-synthase [13] - was accompanied by the dose-dependent reduction of DAF-FM-T fluorescent intensity on average by $20 \%(0.1 \mathrm{mM}$ inhibitor) and $40 \%$ (0.2 mM inhibitor). The growth of fluorescent response with adding SNP occurred in the presence of inhibitor (Fig. 3, 4).

These results show that DAF-FM responds to NO. DAF-FM does not test a level of a wide range of the active nitrogen and oxygen metabolites, for example $\mathrm{NO}_{2}^{-}, \mathrm{NO}_{3}^{-}, \mathrm{ONOO}^{-}, \mathrm{O}_{2}^{-}, \mathrm{H}_{2} \mathrm{O}_{2}$, etc. [4]. There are good reasons to use DAF-FM for detection of nitric oxide in intact cell in our further investigations.

Colocalization of the NO-sensitive dye DAF-FM
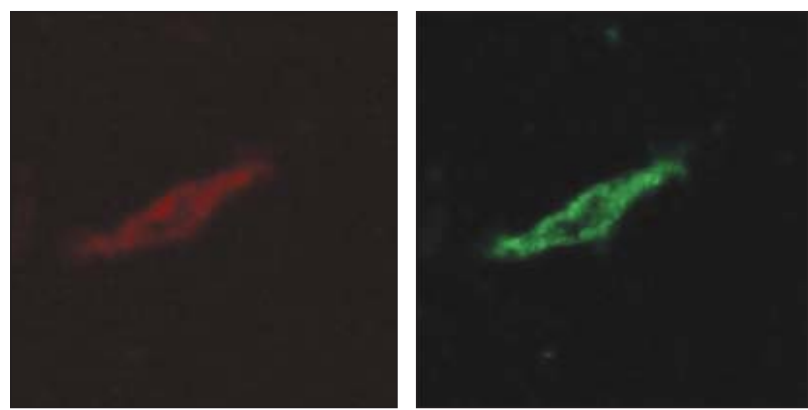

Fig. 5. Distribution of fluorescent dyes MitoTracker Orange $\mathrm{CM}-\mathrm{H}_{2}$ TMRos (left figure, red color) and DAF-FM-T (right figure, green color) in myocyte 

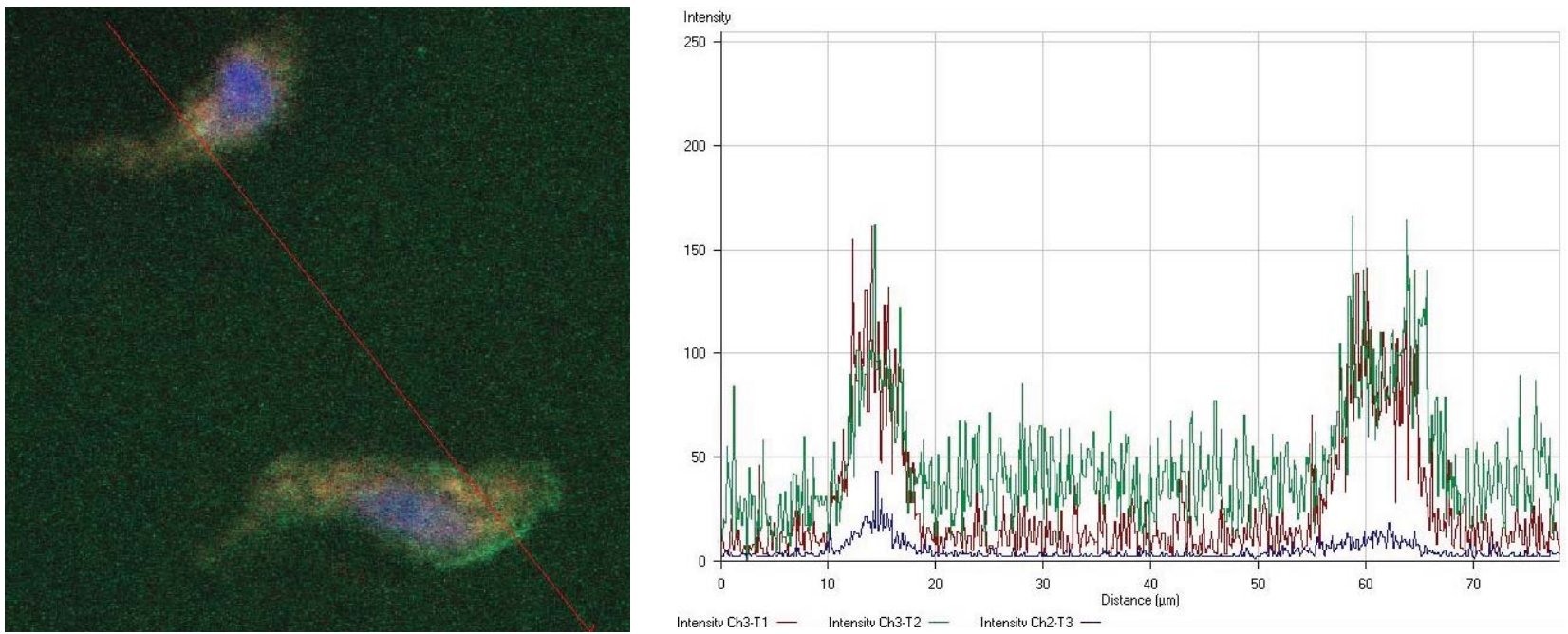

Fig. 6. Comparison of the fluorescent dyes distribution profiles, that are specific for mitochondria (MitoTracker Orange CM-H $\mathrm{H}_{2} \mathrm{M}-$ Ros, red curve, channel 1), nitric oxide (DAF-FM-T, green curve, channel 2) and nucleus (Hoechst 33342, blue curve, channel 3) in two immobilized myocytes

and the specific probe for mitochondria MitoTracker Orange CM-H TMRos, accumulated only in the intact energized organells [14], was demonstrated by the next studies (Fig. 5).

The computer analysis the image outside the cell nucleus has revealed an identical distribution of both fluorescent dyes (Fig. 6).

We have shown the potential presence of NO in mitochondria of uterus myocytes. Nonetheless, the nitric oxide biosynthesis in cells is linked not only with mitochondria. Constitutive NO-synthase is associated with the plasma membrane, sarcoplasmic reticulum and other intracellular structures. NO, synthesized by these structures, can diffuse to mitochondria and vice versa. Further researches are necessary to clarify the subcellular distribution of NOsynthases in the intact cells.

\section{Conclusions}

In this work for the first time the presence of NO in smooth muscle cell mitochondria has been demonstrated using the laser confocal microscopy, NOsensitive probe DAF-FM and specific marker for the functionally active mitochondria MitoTracker Orange CM- $\mathrm{H}_{2}$ TMRos. It has been also shown that the amount of NO changes in the presence of the nitric oxide donor and NO-synthase inhibitor.

\section{REFERENCES}

1. Bryan NS, Bian K, Murad F. Discovery of the nitric oxide signaling pathway and targets for drug development. Front Biosci (Landmark Ed). 2009;14:1-18.

2. Levine AB, Punihaole D, Levine TB. Characterization of the role of nitric oxide and its clinical applications. Cardiology. 2012;122(1):55-68.

3. Danylovich $\mathrm{IuV}$. [Nitric oxide as the regulator of intracellular homeostasis in the uterus myocytes]. Ukr Biokhim Zh (1999). 2012;84(3):5-25.

4. López-Figueroa MO, Caamaño C, Morano MI, Rønn LC, Akil H, Watson SJ. Direct evidence of nitric oxide presence within mitochondria. Biochem Biophys Res Commun. 2000; 272(1):129-33.

5. Giulivi $C$, Kato $K$, Cooper $C E$. Nitric oxide regulation of mitochondrial oxygen consumption I: cellular physiology. Am J Physiol Cell Physiol. 2006;291(6):C1225-31.

6. Shiva $S$. Nitrite: A physiological store of nitric oxide and modulator of mitochondrial function. Redox Biol. 2013; 1 (1):40-4.

7. Nakatsubo N, Kojima H, Kikuchi K, Nagoshi H, Hirata Y, Maeda D, Imai Y, Irimura T, Nagano T. Direct evidence of nitric oxide production from bovine aortic endothelial cells using new fluorescence indicators: diaminofluoresceins. FEBS Lett. 1998;427(2):263-6.

8. Mollard P, Mironneau J, Amedee T, Mironneau C. Electrophysiological characterization of single pregnant rat myometrial cells in short-term primary culture. Am J Physiol. 1986;250(1 Pt 1):C47-54.

9. Danylovych IuV, Danylovych HV, Kolomiiets' OV, Kosterin SO, Karakhim SO, Chunikhin OIu. [Investigation of nitrosactive compounds influence on polarization of the mito- 
chondrial inner membrane in the rat uterus myocytes using potential sensitive fluorescent probe DiOC6(3)]. Ukr Biochem J. 2014;86(1):42-55.

10. Kucherenko ME, Babenuk YuD, Voytsitskyy VM. Modern methods of biochemical studies: tutorials. Kiyv, Fitosotsiotsentr. 2001: 424 p.

11. Kojima H, Nakatsubo N, Kikuchi K, Kawahara S, Kirino Y, Nagoshi H, Hirata Y, Nagano T. Detection and imaging of nitric oxide with novel fluorescent indicators: diaminofluoresceins. Anal Chem. 1998;70(13):2446-53.

12. Babich LG, Shlykov SG, Borisova LA, Kosterin SA. [Energy-dependent $\mathrm{Ca} 2+$-transport in intracellular smooth muscle structures]. Biokhimiia. 1994;59(8):1218-29.

13. Viteček J, Lojek A, Valacchi G, Kubala L. Arginine-based inhibitors of nitric oxide synthase: therapeutic potential and challenges. Mediators Inflamm. 2012;2012:318087.

14. Buckman JF, Hernández H, Kress GJ, Votyakova TV, Pal S, Reynolds IJ. MitoTracker labeling in primary neuronal and astrocytic cultures: influence of mitochondrial membrane potential and oxidants. J Neurosci Methods. 2001;104(2): 165-76.

\section{Ідентифікація оксиду азоту в мітохондріях міоцитів матки}

Ю. В. Данилович, С. О. Карахім, О. В. Коломієць, Г. В. Данилович, С. О. Костерін

Мета. Продемонструвати можливість синтезу NO в інтактних міоцитах матки щурів. Методи. Конфокальна скануюча мікроскопія, NO-чутливий флуоресцентний зонд DAFFM, MitoTracker Orange CM-H TMRos. Результати. Показано базальну продукцію NO в інтактних міоцитах за допомогою флуоресцентного зонду DAF-FM. Внаслідок інкубації клітин 3 донором NO нітропрусидом натрію (SNP) спостерігалось зростання флуоресцентного сигналу DAFFM-T. I навпаки, внесення інгібітора NO-синтази - N-нітроL-аргініну (NA) - призводило до гасіння флуоресценції. Доведено колокалізацію флуоресцентного мітохондріального маркеру MitoTracker Orange CM-H_TMRos та NO-чутливого зонду DAF-FM. Висновки. Вперше показано наявність NO в гладеньком'язових клітинах матки, і зокрема в мітохондріях, із залученням методу лазерної конфокальної мікроскопії, NO-чутливого зонду DAF-FM та специфічного маркеру функціонально активних мітохондрій MitoTracker Orange CM-H $\mathrm{H}_{2}$ TMRos.

Ключ ов і сл о в а: оксид азоту, міометрій, DAF-FM, конфокальна мікроскопія.

\section{Идентификация оксида азота в митохондриях миоцитов матки}

Ю. В. Данилович, С. А. Карахим, О. В. Коломиец, А. В. Данилович, С. А. Костерин

Цель. Продемонстрировать возможность синтеза NO в интактных миоцитах матки крыс. Методы. Конфокальная сканирующая микроскопия, NO-чувствительный флуоресцентный зонд DAF-FM, MitoTracker Orange CM-H TMRos. Результаты. Показана базальная продукция NO в интактных миоцитах с использованием флуоресцентного зонда DAF-FM. Инкубация миоцитов с донором NO - нитропруссидом натрия (SNP) - приводила к повышению флуоресцентного сигнала DAF-FM-T. И наоборот, внесение ингибитора NOсинтазы - N-нитро-L-аргинина (NA) - снижало интенсивность флуоресценции. Показана колокализация флуоресцентного митохондриального маркера MitoTracker Orange CM-H TMRos и NO-чувствительного зонда DAF-FM. Выводы. Впервые показано присутствие NO в гладкомышечных клетках матки, в частности митохондриях, с использованием метода лазерной конфокальной микроскопии, NOчувствительного зонда DAF-FM и специфического маркера функционально активных митохондрий MitoTracker Orange CM-H $\mathrm{H}_{2}$ TMRos.

К л юч е в ы е с л о в а: оксид азота, миометрий, DAF-FM, конфокальная микроскопия.

Received 04.04.2015 